prof. dr. Norbert MEINERS

PHWT University Vechta, Germany

e-mail: meiners@phwt.de

prof. dr. hab. Elmar REUCHER

PHWT University Vechta, Germany

e-mail: reucher@phwt.de

dr. George W. LEESON

University of Oxford, United Kingdom

e-mail: george.leeson@ageing.ox.ac.uk

DOI: $10.15290 /$ ose.2017.02.86.02

\title{
AGE DISCRIMINATING ADVERTISING IN GERMANY: IS THIS AN ISSUE? BASIC STATISTICAL ANALYSIS OF COMPLAINTS TO THE »DEUTSCHE WERBERAT»
}

\begin{abstract}
Summary
Advertisements which discriminate according to age are not uncommon and should not be seen as a side-issue of society, which can be neglected. Therefore, the focus of this paper had as its aim the identification and investigation of specific complaints regarding age discrimination in advertising. This was done by means of long-term monitoring with the purpose of gaining new insights and obtaining valuable information for future research projects. Here the relevant question was: Have complaints about age discriminating advertisements (adverts, spots, posters, online-advertising) been received by the »Deutsche Werberat", a self-regulatory body of the advertising industry which was founded in 1972 ? In order to investigate the question asked, a quantitative time series analysis of the approx. $4500 \mathrm{com}$ plaints lodged with the »Deutsche Werberat« from 2003 to 2013, a period of eleven years, was carried out.
\end{abstract}

Key words: Age, Advertising, Age Discrimination, Complaints, Quantitative Time Series Analysis.

JEL: M31, M37, J14

\section{Background and Initial Situation}

Even though today, almost half of the population of Germany is older than 50 years [Federal Statistics Office, 2009], so that it is already classified as beyond the "relevant 
core advertising target group" of 14 - to 49 -year-olds ${ }^{1}$, many advertising measures are not well-suited to addressing older people - because they are not age-appropriate, and approach them with too much distance and relatively little appreciation [Meiners, Seeberger, 2012; Bieri, Florack, Scarabis, 2006]. For instance, a study by Gassmann/Reepmeyer shows that $68 \%$ of seniors interviewed do not identify with the advertising themes surrounding them [Gassmannm, Reepmeyer, 2006]. A different study comes to the conclusion that $50.2 \%$ of older residents do not agree with the statement that the presentation of older people in advertising reflects reality [Sonnenschein, 2008]. Advertising either ignores older people or presents them as ridiculous [BBS \& Partner, 2005]. As a result, it is not surprising that according to GREY, $31 \%$ of older people feel that advertising does not take them seriously or that it devalues them [GREY, 2005].

The studies mentioned above by way of example demonstrate that discrimination based on age is far from rare in advertising and that it is therefore not an unusual occurrence in society, which could be ignored. Against the background of demographic change ${ }^{2}$, this topic is in fact becoming ever more important [Scholl, 2006]. Very little reliable data currently exists for the topic of "age-discriminating advertising" so that there is currently a large gap both in science and in practice. Looking through the relevant academic literature quickly reveals that academia has only rarely dealt with this group of issues so that a deficit can be identified regarding knowledge accumulated so far - particularly in German-speaking academic literature. Academics in Germany only began to focus on this topic in the 1980s [Kübler, 2009; Geyer, 2008]. The situation is very different in the United States: Here, initial research as well as political initiatives to combat age discrimination have been taking place in both public and private arenas since the 1960s (e.g. Anti-Ageism Taskforce) [Rothermund, Mayer, 2009; Stereotype? Frauen und Männer..., 2008].

\section{Research Findings to Date}

The results of the studies in the USA and other countries are fairly pertinent and largely homogeneous. Research to date has clearly found that advertising either ignores older people altogether or that otherwise, older people are often addressed in a discriminating way ${ }^{3}$. For instance, several Anglo-American studies point to a noticeable under-representation of older people in general and older women in particular. And this is independent of whether the research studies were carried out at the start of the 1970s or three decades later [Lauzen, Dozier, 2005; Robinson, Skill, Turner,

\footnotetext{
${ }^{1}$ In Germany, the target group of 14- to 49-year-olds was declared to be the relevant core advertising target group in the 1990s. This target group definition originates from the USA. There, this target group was defined as the sales strategy of the American network ABS around 50 years ago [Jäckel, 2009].

2 "The term 'demographic change' refers to changes within population groups such as the composition and fluctuation of the total number of individuals. These can be caused by births, deaths, ageing of the population as well as migrations" [Geyer, 2008, p. 28].

3 "One reason for this absence, which is largely and significantly the fault of the advertising industry, is the continued focus on the relevant advertising target group aged up to 49 years" [Gonser, 2009, p. 73; also see: Mayer, Lukas, Rothermund, 2005].
} 
2004; Coltrane, Messino, 2000; Roy, Harwood, 1997; Robinson, Skill 1995; Moore, Cadeau, 1985; Hiemstra, Goodman, Middlemiss, Vosco, Ziegler, 1983; Francher, Jay 1973]. Research in Germany comes to similar conclusions. However, the degree of under-representation varies greatly [Burgert, Koch, 2008; Femers, 2007; Löffler, 2006; Röhr-Sendelmeier, Ueing, 2004; Kessler, Rakoczy, Staudinger, 2004; Jürgens, 1994; Bosch, 1986; Hagen, 1985; Hasenteufel, 1980; Horn, Naegele, 1976]. In addition, advertising often only includes older people as passive marginal figures, i.e. in supporting roles or in the background, so that they are often only presented superficially [Roy, Harwoods, 1997; Tuppers, 1995; Bosch, 1990; Swayne, Greco, 1987]. Moreover, presentations of older people often tend to be unrealistic or distorted, with advertising either depicting them one-sidedly - particularly in any content regarding age-related problems - or ridiculing them in a stereotyped, exaggerated image [Harwood, 2007; Lee, Carpenter, Meyers, 2007; Miller, Leyell, Mazachek, 2004; Roy, Harwood 1997; Hummert, Garstka, Shaner, Strahm, 1994; Kite, Deaux, Miele 1991; Schmidt, Boland, 1986]. Advertising not only portrays older people negatively but often also overly positively, e.g. as exaggeratedly happy, vivacious, active, attractive and socially integrated. Any risks associated with ageing, such as illness, frailness, lower performance, feebleness, or social isolation often remain hidden [Schmitt, 2004; Härtl-Kasulke, 1998; Schmitz-Scherzer, Backes, Friedrich, Karl/Kruse, 1994; Wilbers, 1986; Dennersmann, Ludwig, 1986]. It is also noticeable that advertising rarely shows older people alone but often as interacting with other age groups [Prieler, 2008; Miller, Leyell, Mazachek, 2004; Swayne, Greco, 1987].

The studies mentioned above reveal that the type and frequency with which older people are presented in advertising are relatively well-researched areas. However, research to date - both in the German- and in the English-speaking regions - consists primarily of studies which analyse advertising by content and which also only look at a small proportion of the media landscape [Sechster Bericht zur Lage der älteren Generation in der Bundesrepublik Deutschland, 2010; Jäckel, 2009]. What is missing is research as well as practice-based reflection using an empirical research method in order to answer the question how older people perceive the depiction of age presented in advertising and whether they themselves experience this as discriminating [Rothermund, Mayer 2009; Schorb, Hartung, Reißmann, 2009]. In addition, there is a lack of research looking not just at excerpts of age-discriminating advertising (e.g. only advertising on posters) but across the entire media landscape involving all types of media (posts, ads, spots, online advertising, etc.). The present investigation intends to contribute to closing this research gap. 


\section{Objective, Research Question and Method}

\subsection{Objective}

The present situation demonstrates that the both economically and socially important area of age-discriminating advertising has been researched insufficiently and requires further research efforts. As a result, this research paper aims to make a clarifying contribution to answering the topical question of how older people in Germany perceive and experience advertising. This will go beyond the findings of research based on an analysis of content, surveys and case studies and instead focus on statistical data obtained from a neutral source as well as independently from scientific objectives. The objective of this research paper is to identify and analyse complaints regarding age-discriminating advertising in the Federal Republic of Germany, which were submitted to the »Deutsche Werberat" (German Advertising Standards Committee), the cross-media internal control body for the advertising industry, in order to obtain new findings on this topic as well as valuable clues as to future research tasks.

The "German Advertising Standards Committee" was founded by the Central Association of the German Advertising Trade (ZAW) in November 1972. With the "German Advertising Standards Committee", advertising companies, media and agencies created a non-state supervisory body supporting commercial advertising trade in Germany. Advertising by companies in Germany may be governed by law (e.g. the Act Against Unfair Practices). But the "German Advertising Standards Committee" allows consumers to object to contents in advertising where advertising measures cannot be rejected on legal grounds, but where the citizens in question view them as objectionable and therefore as unwanted based on their perceptions and values [German Advertising Standards Committee, 2014].

\subsection{Research Questions}

Based on prior theoretical considerations and research to date, the following leading research question can be deduced for the topic investigated here: Has the "German Advertising Standards Committee", the internal control body for the advertising industry founded in 1972, received complaints from the population or public bodies regarding age-discriminating advertising measures (ads, spots, posts, online advertising)? Two further specific research questions can in turn be deduced: 1.) How did the number of such complaints develop over time? 2.) In what industries can agediscriminating advertising be identified? Responses to these research questions will provide concrete indications as to how older people in Germany perceive and experience advertising. These can then in turn be used by trade (and particularly the advertising trade) as well as to create a more generation-friendly social depiction of age. As a result, the present research agrees with a thesis by Bieri/Florack/Scarabis, which states that the knowledge of the special characteristics of older consumers can be put to very productive use [Bieri, Florack, Scarabis, 2006]. 


\subsection{Method and Collection}

To answer these questions, a time series analysis ${ }^{4}$ was performed for the 4537 complaints received by the "German Advertising Standards Committee" between 2003 and 2013, i.e. in a period of eleven years. The data required for this long-term research was made available by the "German Advertising Standards Committee" on 31 March 2014 after a written request and then analysed by the author based on quantitative aspects [Schaich, Münnich, 2001]. Up to the present day, no research with a similar research question or method has been presented in academic literature. This was also confirmed by a literature research performed prior to this investigation (as at: January 2014). The new findings obtained in the context of this investigation thus constitute a valuable further development of scientific economics research on this topic.

Before presenting the research results of this investigation in detail below, the term "age-discriminating advertising" will first be defined and explained, because a discussion of the complaints to the "German Advertising Standards Committee" assumes a careful specification of the term. In addition, the term "age-discriminating advertising" is often understood and defined quite differently in economic and gerontological scientific literature.

\section{Definition of "Age-Discriminating Advertising"}

Discrimination (lat.: discriminare $=$ to separate) is generally understood to mean "[...] a type of disadvantaging, unequal treatment or non-observance of individuals or groups who perceive this as more or less painful, disconcerting or outrageous. The term age discrimination is used if people experience disadvantages based merely on their higher chronological age" [Sechster Bericht zur Lage der älteren Generation in der Bundesrepublik Deutschland, 2010 p. 250; also see Rothermund, Mayer, 2009]. The term "age discrimination" may have been included in the "DUDEN", the dictionary of the German language, since 2006 [DUDEN Wörterbuch der deutschen Sprache, 2006 p. 176]. But it is still rarely used in Germany and in addition - including in the relevant academic literature - is interpreted, used and valued very differently based on the social, cultural and political context [Rothermund, Mayer, 2009].

In Germany, under $\$ 1$ of the "General Equal Treatment Act (AGG)", discrimination based on age is prohibited in relation to employment and professions, to socalled mass transactions of everyday life as well as to insurances. With the AGG, which became effective on 18 August 2006, the Federal Republic of Germany met its obligation to implement EU anti-discrimination guidelines to this effect [Geyer, 2008]. Age within the meaning of the AGG refers to a person's biological age, i.e. any age. By contrast, federal law and the constitutions of the individual federal states

\footnotetext{
${ }^{4}$ In the encyclopaedia "Gabler Wirtschaftslexikon", Kamps defines time series analysis as follows: "Process of deconstructing a time series into its components (time series components) based on a given empirical time series process" [Kamps, 2014].
} 
include no explicit age discrimination prohibition [General Equal Treatment Act (AGG), 2006]. In Europe, the constitutions of Sweden, Finland and Switzerland already contain such a prohibition [Federal Anti-Age-Discrimination Office, 2012].

According to the "principles of the German Advertising Standards Committee on vilification and discrimination against individuals" (2004 version), commercial advertising "[...] must use no images or text that might violate human dignity and a general sense of decency. In particular, advertising - particularly aimed at children and young people - must not give the impression that specific people are inferior or that they can be treated differentially in society, professional life and families. Above all, no statements or depictions may be used, which discriminate against people based on their gender, ancestry, race, language, origins, beliefs, political views, age or appearance [...]" [German Advertising Standards Committee, 2014].

\section{Findings}

The analysis of the 4537 complaints submitted to the "German Advertising Standards Committee" in the period from 2003 ( $\left.\mathrm{t}_{0}\right)$ to 2013 ( $\left.\mathrm{t}_{10}\right)$ led to the following main findings:

1. In the eleven years under investigation, 197 complaints related to allegations regarding discrimination against groups of individuals (women, men, foreigners, etc.). This corresponds to $4,34 \%$ of all complaints submitted. Of these 197 complaints, 31 contained the allegation of discrimination against older people. This corresponds to a share of $15,74 \%$ of complaints relating to groups of individuals and a share of $0,68 \%$ of all complaints submitted.

2. The number of complaints containing an allegation of discrimination against older people barely changed during this period.

3. At $19,35 \%$, most complaints containing an allegation of discrimination against older people came from the industry "entertainment electronics, communication technology (excluding computers) and telecommunications".

The following remarks present the most important research findings of this investigation in more detail:

The "German Advertising Standards Committee" received a total of 4537 complaints in the eleven-year period under investigation, which averages at around 412 complaints per year. As illustrated in chart 1, the two years with the highest number of complaints were 2013 (522) and 2012 (479). The two years with the lowest number of complaints were 2006 (341) and 2003 (360). Even though the values for the years vary slightly over the period under investigation, a clear trend towards an increase in the number of complaints can be identified. As a result, the volume of complaints went up by almost half (+45\%) between 2003 (360) and 2013 (522). In order to quantify the relationship between the number of complaints (y) and the years under investigation $(t)$, the following regression function was determined in the context of a simple (bivariate) regression analysis using a linear trend $\hat{y}=n+m \times t: \hat{y}=$ $345,45+13,4 \times t$ [Fahrmeir, Künstler, Pigeot, Tutz, 2010; Rößler, Ungerer, 2008)]. 
As a result, a positive increase in the number of complaints over the eleven-year period under investigation could be identified. The correlation coefficient is $r=0,84$ and thus points to a high statistical dependence of the above measurement data ${ }^{5}$. Time series analyses using the "higher degree polynomials" approach did not result in any new findings.

\section{Complaints over time (total complaints)}

CHART 1.

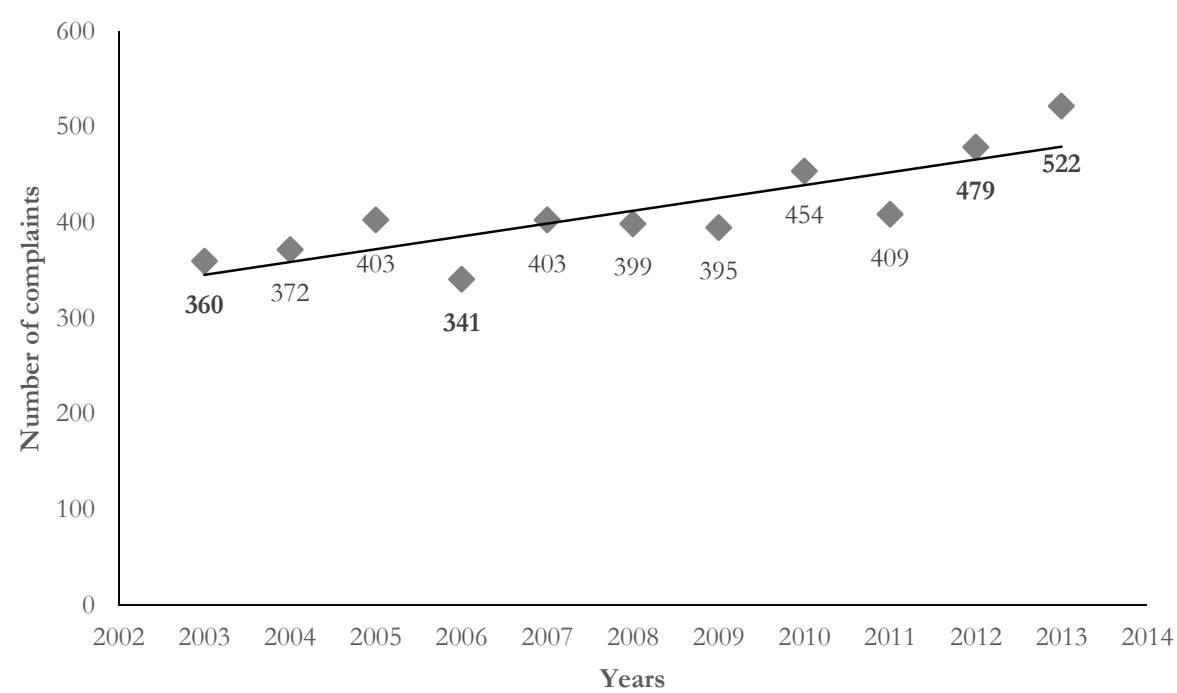

During the period under investigation, 197 complaints were received containing an allegation of discrimination against groups of individuals (women, men, foreigners, etc.). This averages at around 18 complaints per year. In 2012, the year in which most complaints were received, complaints were launched against a total of 29 advertisements - see Chart 2. Nevertheless, in the following year, 2013, the number of such complaints fell again to the third lowest value. By comparison, the lowest number of complaints containing an allegation of discrimination against groups of individuals were received in 2003 (7 complaints) and 2009 (10 complaints). Using linear trends for the period $2003\left(\mathrm{t}_{0}\right)$ to $2013\left(\mathrm{t}_{10}\right)$, a simple regression analysis resulted in the following regression function: $\hat{y}=13,64+0,85 \times t$. This reveals a slight positive increase in such complaints over the entire period under investigation, even though the correlation coefficient $r=0,43$ points to a slightly lower statistical relationship between the above measurement values ${ }^{6}$.

\footnotetext{
${ }^{5}$ The standard deviation is $\mathrm{S}=30,086$ and the coefficient of determination is $\mathrm{R}^{2}=0,697$.

${ }^{6}$ The standard deviation is $\mathrm{S}=6,205$ and the coefficient of determination is $\mathrm{R}^{2}=0,188$.
} 
CHART 2.

Complaints over time which contain an allegation of discrimination against groups of individuals (woman, men, foreigners, etc.)

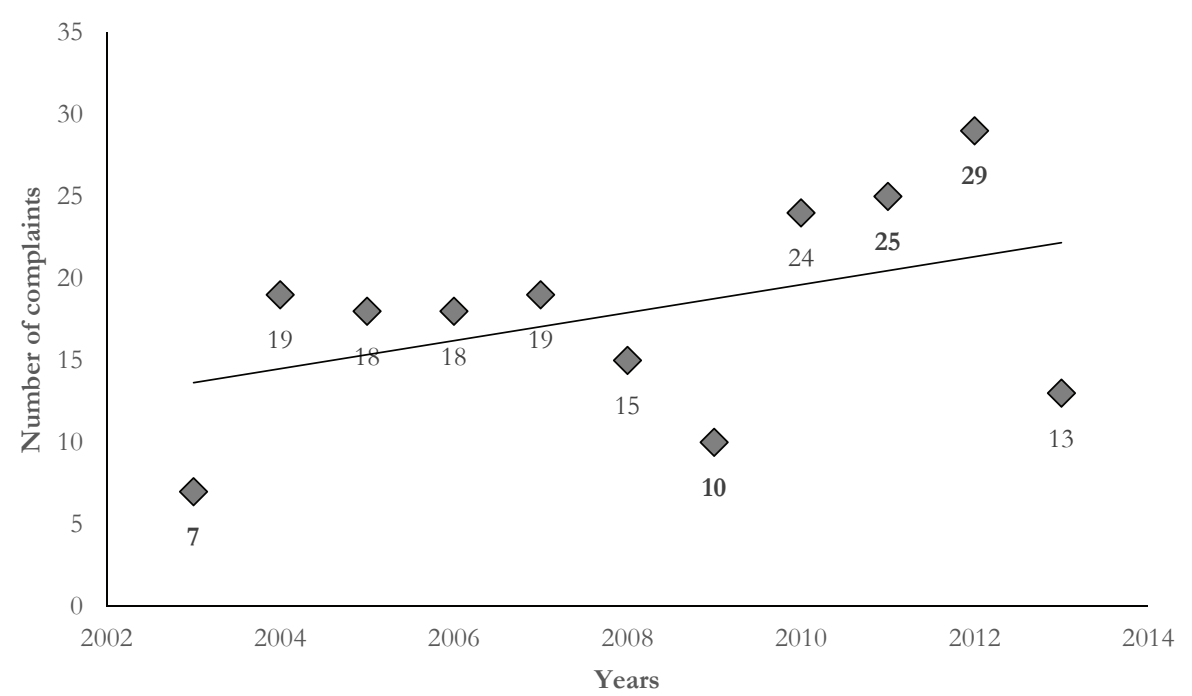

A total of 31 complaints containing an allegation of discrimination against older people were received in the period from $2003\left(t_{0}\right)$ to $2013\left(t_{10}\right)$. This averages at around 3 complaints per year. As illustrated in chart 3 , the highest number of such complaints was received in 2007 (6). The two years with the lowest number of complaints were 2009 and 2013 ( 1 each). A simple regression analysis resulted in the following linear regression function: $\hat{y}=3,27-0,09 \times t$. As a result, the number of such complaints was nearly constant over the relevant period under investigation. The correlation coefficient is $r=0,21$ and thus points to a low statistical dependence of the above measurement data 7 .

7 The standard deviation is $S=1,518$ and the coefficient of determination is $R^{2}=0,042$. 
CHART 3.

Complaints over time which contain an allegation of discrimination against older people

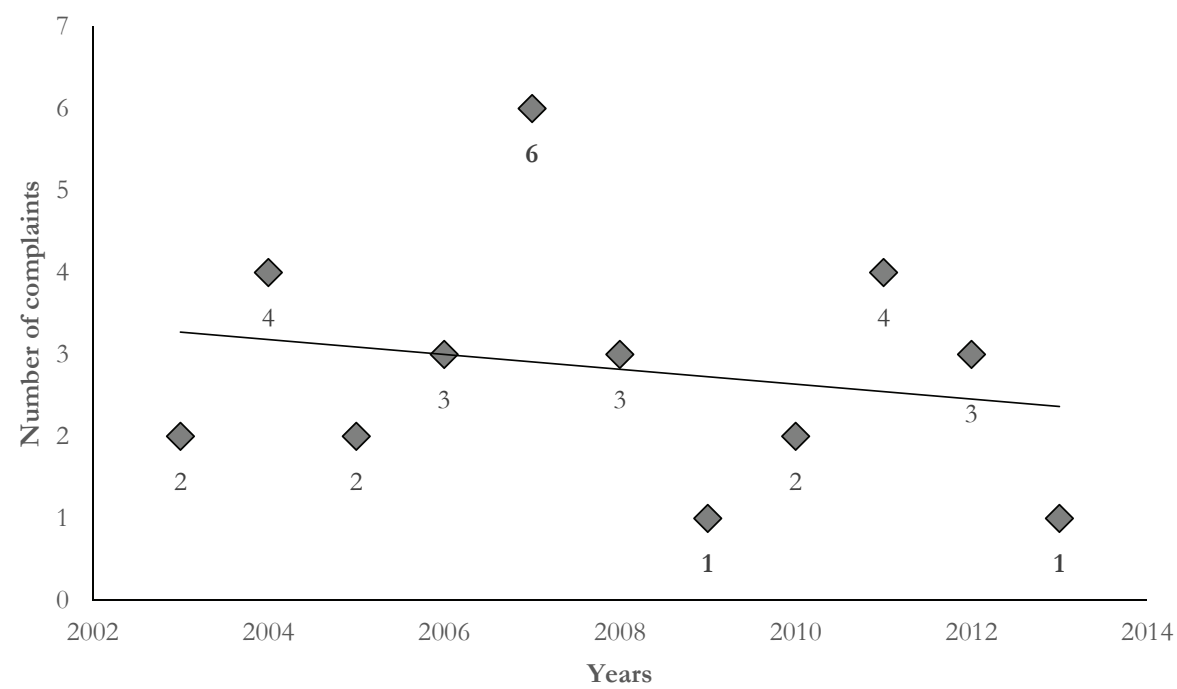

The proportion of complaints involving an age-discrimination background of the total number of complaints submitted to the "German Advertising Standards Committee" averages at 0,68\%. The relative mean however fluctuates over the elevenyear period and varies between 1,49\% (2007) and 0,19\% (2013). To quantify this relation, the following linear regression function was determined: $\hat{y}=1,06+0,1 \times \mathrm{t}$. The correlation coefficient is $r=0,43$. This means that there is hardly any positive linear relationship between the two variables above. However, it must be stressed that at least one complaint about age-discriminating advertising was submitted each year.

As illustrated in chart 4, time series analysis further shows a clear polarisation of the complaints submitted to the "German Advertising Standards Committee" in terms of specific industries. The three industries with the highest number of complaints regarding age-discriminating advertising were: 1.) "Entertainment electronics, communication technology (excluding computers) and telecommunications" at 19,35\%, 2.) "Other services" at 16,13\% and 3.) "Credit business, insurances and building societies" at $12,90 \%$. Almost half of complaints (48,38 \%) containing an allegation of discrimination against older people relate to these three industries. The other half of such complaints $(51,62 \%)$ is split between a further 12 industries (e.g. "Computers", "Clothes", "Tourism"). In these industries, the number of complaints submitted was significantly below $10 \%$ for each. 


\section{CHART 4.}

\section{Industries with the highest number of complaints regarding age- discriminating advertising}

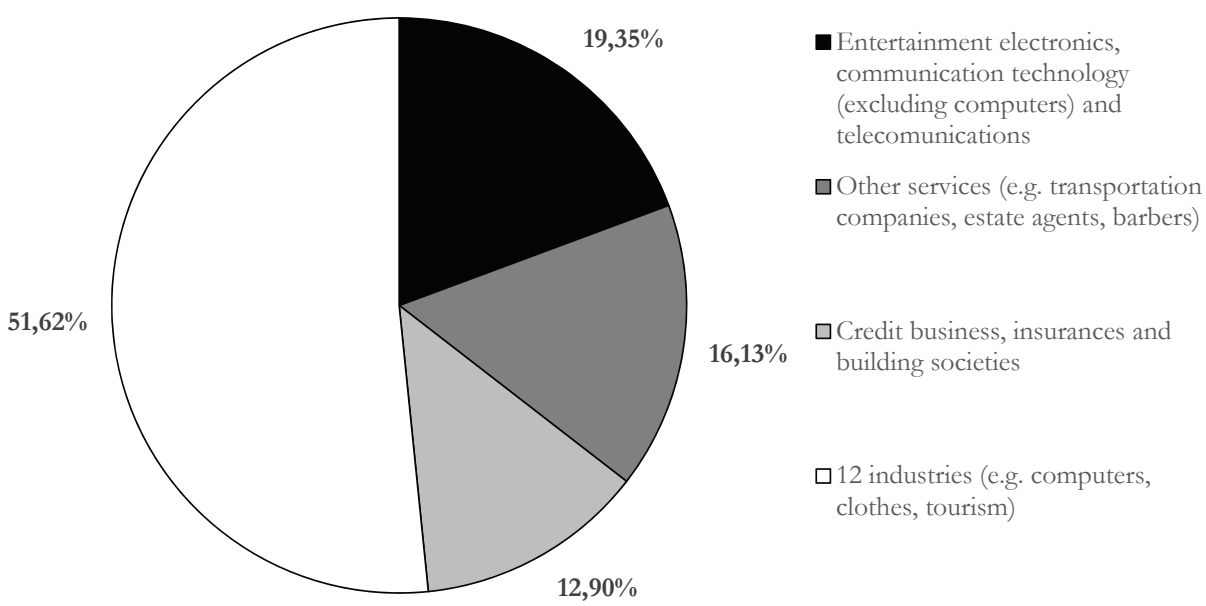

Below, the research findings presented above will be scrutinised critically.

\section{Discussion}

The findings presented here show that the number of complaints containing an allegation of discrimination against older people is still relatively low at $15.74 \% \mathrm{com}$ pared to the number of complaints containing an allegation of discrimination against groups of individuals (women, men, foreigners, etc.). The findings thus differ from those of a Europe-wide survey on experiences with discrimination from 2003, according to which the criterion of age was said to be the most frequent reason for discrimination (other criteria include gender, race, religion, physical disability, sexual orientation) [Kuratorium Deutsche Altershilfe, 2006].

The present results also contradict the supposition that complaints containing an allegation of discrimination against older people have been regressive in the past five years [Sechster Bericht zur Lage der älteren Generation in der Bundesrepublik Deutschland, 2010]. Companies continue to use advertisements which present positively exaggerated, deficient or humorously grotesque images of age and which can therefore be perceived or experienced as discriminating. It is unclear why companies hold on to age-discriminating advertising, given that it is not in the economic interest 
of companies to alienate older people through conscious discrimination ${ }^{8}-$ as these are potential or even current buyers. On the one hand, this would reduce revenue from operations, and on the other hand, younger buyers might then also learn of such discrimination through negative mouth-to-mouth propaganda and respond with outrage, by terminating the business relationship or even swapping to a different provider. Consumers tend to respond to discrimination with disapproval and show solidarity for the victims [Meiners, Schwarting, Seeberger, 2010; Sechster Bericht zur Lage der älteren Generation in der Bundesrepublik Deutschland, 2010].

Even though a survey by Dennersmann/Ludwig [1986] evidences that ads for pharmaceutic products dominate age-specific advertising with a share of almost $60 \%$, the results of the present study show that most complaints regarding an age-discrimination background originate from the industry entertainment electronics, communication technology (excluding computers) and telecommunications. An investigation by Horn/Naegele even provides evidence that ads for pharmaceutical products dominate even more clearly in advertisements aimed at older people. According to this, around nine out of ten age-specific ads are for pharmaceutical products. Services, clothes and food/drinks are advertised much more rarely [Horn, Naegele, 1976]. However, based on the present findings, no relationship between the dominance of specific products in age-specific advertising and the frequency of complaints containing an allegation of discrimination against older people can be identified.

No matter how impressive the results of this study may be, they are nevertheless in no way sufficient as compelling evidence for an increase or decrease in discrimination against older people in advertising. However, the following hypothesis can be deduced from the present findings: Even though the topic of "age-discriminating advertising" has attracted more and more attention in recent years, and new research is documenting a paradigm shift in the treatment of old people and demanding a welcome move away from such advertising, discrimination against older people continues to exist in advertising. As such, it must be viewed as problematic because such advertising messages can sustainably influence the image of age in society. This is relevant in that "[...] images of age can impact on individual and collective behaviour [...]" [Röhr-Sendlmeier, Ueing, 2004 p. 61]. In addition, advertising also influences the self-image of older people because people increasingly construct their reality based on the impressions that they gain from the media [Kroeber-Riel, Weinberg, Gröppel-Klein, 2009]. Therefore, advertising is expected to have a great influence on individual self-images of age as well as on the images others have of age. It is therefore barely possible to overemphasise the social significance of advertising, as McLuhan already realised more than 60 years ago [McLuhan, 1951]: "Historians and archaeologists will one day discover that the ads of our time are the richest and most faithful reflections that any society ever made of its entire range of activities" [McLuhan, 1992 , p. 268] $]^{9}$.

\footnotetext{
${ }^{8}$ For more information about older people as a group of buyers, see [Meiners, Reidl, Seeberger, 2011].

${ }^{9}$ However, Jäckel stressed " $[\ldots]$ that advertising would not by itself be able to define the image of age" [Jäckel, 2009, p. 143].
} 


\section{Limitations}

Like any other investigation, the study described here also has limitations: One important limit of the present investigation is the fact that data from only a single source was used (in this case: the "German Advertising Standards Committee") and that as a result, the focus was exclusively on the complaints submitted to this source. The unknown number of advertisements, which the parties affected valued as agediscriminating but where complaints were sent to a different office, is likely to be significantly higher - given the studies quoted above. In addition, the data of this investigation exclusively relate to complaints against age-discriminating advertising in one country (in this case: the Federal Republic of Germany). However, perceptions and values can be very different in different countries, cultural groups and societies, and can vary greatly. The findings can therefore neither be generalised nor simply be compared with studies from other countries. They cannot even be compared with other studies from Germany without restrictions: Different research designs and disparate definitions of age discrimination or age-discriminating advertising prevent this. In addition, the data of this investigation cannot be assigned to the persons making the complaints. The age of the persons perceiving the advertisements as age-discriminating can thus not be determined. Though it is not expected, it is possible that younger people might have complained to the "German Advertising Standards Committee" about age-discriminating advertising. Finally, the data from this investigation primarily relate to perceived, i.e. subjectively felt, cases of discrimination (in this case: advertising to which the population or public bodies objected as discriminating). However, merely subjectively perceived discrimination is not a criterion for the actual presence of discrimination [Rothermund, Mayer, 2009]. Any discrimination wrongly branded as such in complaints submitted to the "German Advertising Standards Committee" can however not be distinguished from actual cases of discrimination. As a result, evidence for objective age discrimination can only be approximated in this investigation.

\section{Conclusion and Prospects}

To summarise, it can be said that an examination of the topic of "age-discriminating advertising" is still in its early stages in the Federal Republic of Germany and research to date is astonishingly limited. This was also confirmed by the literature research performed prior to this investigation. In particular, the question of how older people perceive and experience advertising - both in the German- and in the English-speaking regions - has not been sufficiently researched academically and as such merits further research. The present long-term analysis therefore provides new findings regarding the questions how older people perceive the image of age depicted in advertising and whether they experience this as discriminating. Even though this investigation is based on statistical data obtained from a neutral source and independently of scientific objectives, the findings are insufficient as compelling evidence 
for an increase or decrease in discrimination against older people in advertising. As a result, any inference of observable age effects on discrimination based on age will always remain hypothetical in an analysis of such statistics. It can be supported by plausibility checks, but not be evidenced definitively [Rothermund, Mayer, 2009; Bamberg, Bauer, 2007; Hartung, 2005].

A follow-up study based on the present findings is already being planned, which will analyse all complaints submitted to the "German Advertising Standards Committee" without exception - i.e. from the date when the internal control body was founded in 1972 until the present time. This study covering four decades is to minimise not just the temporal restrictions of the present investigation (in this case: from 2003 to 2013) but also to present a broader picture of age-discriminating advertising in Germany. To supplement this, comparable data from other sources (e.g. Zentrale zur Bekämpfung unlauteren Wettbewerbs e.V., Verein für lautere Heil- und Lebensmittelwerbung e.V.) are also to be collected and examined. As soon as assured findings are available, they will be exclusively presented here. It remains to be seen what findings regarding this topic can be expected in the future.

In terms of prospects, it can be said that cases of age-discriminating advertising should generally be researched more strongly and systematically in order to collect further evidence for the existence of age discrimination and to create greater transparency of this economically and socially relevant topic. Only an interdisciplinary research approach would make sense for a further analysis of this topic. This is because only a cooperation between sociology, psychology, medicine, political and economic sciences can achieve targeted research into the topic of "age-discriminating advertising", which will be able to uncover and explain the multi-dimensional connections within this construct. This is the only way to trigger an open discussion and hence an exchange of information from different perspectives [Geyer, 2008]. Systematic knowledge about age-discriminating advertising must of course also be obtained across generations because everyone of whatever age has an image of age [Renn, 2006].

\section{Acknowledgements}

We thank the »Deutsche Werberat« for providing the requested data and for the support.

\section{References}

Allgemeines Gleichbehandlungsgesetzes (AGG) 2006, Stand: 03.04.2013, http://gesetze-im-internet.de/bundesrecht/agg/gesamt.pdf (retrieved: 03.07.2014). Altersdiskriminierungsstelle des Bundes (ed.), 2012, Benachteiligung aufgrund des Lebensalters in der praktischen Arbeit von zivilgesellschaftlichen Organisationen, Antidiskriminierungsstelle des Bundes, Berlin. 
Bamberg G., Bauer F., 2007, Statistik, Oldenbourg Wissenschaftsverlag, München.

BBS \& Partner, 2005, Kommunikation 50plus, http://www.bbs.de/50plus/worum/ (retrieved: 18.09.2014).

Bieri R., Florack A., Scarabis M., 2006, Der Zuschnitt von Werbung auf die Zielgruppe älterer Menschen, „Zeitschrift für Medienpsychologie“, Vol. 18, No. 1.

Bosch E. M., 1990, Altersbilder in den bundesdeutschen Medien, [in:] Aktive Mediennutzung im Alter - Modelle und Erfahrungen aus der Medienarbeit mit älteren Menschen, Straka, G.A./Fabian, T./Will, J. (Eds), Asanger Verlag, Heidelberg.

Bosch E.-M., 1986, Ältere Menschen und Fernsehen. Eine Analyse der Konstruktion von Altersdarstellungen in unterhaltenden Programmen und ibre Rezeption durch ältere Menschen, P. Lang Verlag Frankfurt a.M..

Burgert C., Koch T., 2008, Die Entdeckung der Neuen Alten? Best-Ager in der Werbung, [in:] Stereotype? Frauen und Männer in der Werbung, C. Holtz-Bacha (eds.), VS Verlag, Wiesbaden.

Coltrane S., Messino M., 2000, The Perpetuation of Subtle Prejudice: Race and Gender Imagery in 1990s Television Advertising, "Sex Roles", Vol. 42, No. 5/6.

Dennersmann U., Ludwig R., 1986, Das gewandelte Altenbild in der Werbung - Ergebnisse einer neueren Studie aus dem Jahre 1985, „Zeitschrift für Gerontologie“, No. 19.

Deutscher Werberat 2014, http://www.werberat.de (retrieved 09.12.2014).

DUDEN Wörterbuch der deutschen Sprache, 2006, Bibliographisches Institut, München.

Fahrmeir, L., Künstler, R., Pigeot, I., Tutz, G. 2010, Statistik - Der Weg zur Datenanalyse, Springer Spektrum, Heidelberg.

Federal Statistics Office, 2009, Bevölkerung Deutschland bis 2060, https:/ /www.destatis.de/ DE/Publikationen/Thematisch/Bevoelkerung/VorausberechnungBevoelkerung/ BevoelkerungDeutschland2060Presse5124204099004.pdf?_blob=publicationFile, (retrieved 05.11.2014).

Femers S., 2007, Die ergrauende Werbung. Altersbilder und werbesprachliche Inszenierungen von Alter und Altern, VS Verlag für Sozialwissenschaften, Wiesbaden.

Francher J. S., Jay J., 1973, "It's the Pepsi Generation...": Accelerated Aging and the Television Commercial, "International Journal of Aging and Human Development", Vol. 4, No. 3.

Gassmann O., Reepmeyer G., 2006, W achstumsmarkt Alter: Innovationen für die Zielgruppe $50+$, Hanser Verlag, Wien.

General Equal Treatment Act (AGG) 2006: Stand: 03.04.2013, http:/ /gesetze-im-internet.de/ bundesrecht/agg/gesamt.pdf (retrieved: 03.07.2014).

German Advertising Standards Committee 2014, http://www.werberat.de (retrieved: 09.12.2014).

Geyer S., 2008, Ageism: Diskriminierung älterer Menschen, VDM Verlag Dr. Müller, Saarbrücken.

Gonser N., 2009, Perspektiven zur Erforschung medialer Gratifikationen im höheren Lebensalter, [in:] Medien und höheres Lebensalter, B. Schorb, A. Hartung, W. Reißmann (eds.), VS-Verlag, Wiesbaden. 
GREY 2005, MASTER Consumer - Warum ignoriert das Marketing die kaufkeräftigste Generation aller Zeiten?, http:/ /www.grey.de/gww_studien/gww_studien\%20-\%20 master_consumer.pdf (retrieved: 17.01.2015).

Hagen R.A., 1985, Die Medien und der ältere Mensch. Eine Analyse des Altersbildes in Fernsebsendungen von $A R D$ und $Z D F$, Dissertation, Universität Bonn, Bonn.

Härtl-Kasulke C., 1998, Marketing für die Zielgruppe ab 50: Kommunikationsstrategien für 50plus und Senioren, Luchterhand, Neuwied.

Hartung J., 2005, Statistik, Oldenbourg Verlag, München.

Harwood A., 2007, Understanding communication and aging, SAGE Publications, Los Angeles.

Hasenteufel R., 1980, Die Darstellung alter Menschen in der Anzeigenwerbung, „Zeitschrift für Gerontololgie“, No. 6.

Hiemstra R., Goodman M., Middlemiss M. A., Vosco R., Ziegler N., 1983, How older persons are portrayed in television advertising: implications for educators, "Educational Gerontology", Vol. 9, No. 2/3.

Horn M., Naegele G., 1976, Gerontologische Aspekte der Anzeigenwerbung. Ergebnisse einer Inhaltsanalyse von Werbeinseraten für ältere Menschen und mit älteren Menschen, „Zeitschrift für Gerontologie“, No. 6.

Hummert M. L., Garstka T. A., Shaner J. L., Strahm S., 1994, Stereotypes of the elderly held by young, middle-aged, and the elderly adults, "Journal of Gerontology: Psychological Sciences", Vol. 49, No. 5.

Jäckel M., 2009, Ältere Menschen in der Werbung, [in:] Medien und höheres Lebensalter, B. Schorb, A. Hartung, W. Reißmann (eds.), VS Verlag, Wiesbaden.

Jürgens H.-W., 1994, Untersuchung zum Bild der älteren Menschen in den elektronischen Medien, [in:] Unabhängige Landesanstalt für das Rundfunkwesen (eds.), ULR-Schriftenreihe Themen - Thesen - Theorien, Bd. 4, Kiel.

Kamps U., 2014, Zeitreihenanalyse, http://wirtschaftslexikon.gabler.de/Definition/ zeitreihenanalyse.html (retrieved: 03.07.2014).

Kessler E.-M., Rakoczy K., Staudinger U. M., 2004, The Portrayal of the older people in prime television series: The match with gerontological evidence, "Ageing and Society", Vol. 24, No. 4.

Kite M. E., Deaux K., Miele M., 1991, Stereotypes of old and young: Does age outweigh gender?, "Psychology and Aging", Vol. 6, No. 1.

Kroeber-Riel W., Weinberg P., Gröppel-Klein A., 2009, Konsumentenverhalten, Verlag Franz Vahlen, München.

Kübler H.-D., 2009, Medien und Alter als Gegenstand der Medienforschung in Deutschland, [in:] Medien und höheres Lebensalter, B. Schorb, A. Hartung, W. Reißmann (eds.), VS Verlag, Wiesbaden.

Kuratorium Deutsche Altershilfe, 2006, Altersdiskriminierung-Alterspotentiale. Wie siebt der Alltag aus? Dokumentation der Veranstaltung am 12. Dezember 2005 im Maternushaus in Köln, farbo print + media, Köln.

Lauzen M. M., Dozier D. M., 2005, Recognition and respect revisited: Portrayals of age and gender in prime-time television, "Mass Communication and Society", Vol. 8, No. 1. 
Lee M. M., Carpenter B., Meyers L. S., 2007, Representations of older adults in television advertisements, "Journal of Aging Studies", Vol. 21, No. 1.

Löffler H., 2006, Wo sind sie denn? Auf der Suche nach Senioren in der Anzeigenwerbung, [in:] Jabrbuch Seniorenmarketing 2006/2007, H. Meyer-Hentschel, G. Meyer-Henschel (eds.), Deutscher Fachverlag, Frankfurt am Main.

Mayer A.-K., Lukas C., Rothermund K., 2005, Vermittelte und individuelle Vorstellung vom Alter-Altersstereotype, „Spiel“", No. 24.

McLuhan M., 1951, The Mechanical Bridge: Folklore of Industrial Man, The Vanguard Press, New York.

McLuhan M., 1992, Die magischen Kanäle. Understanding Media, Econ Verlag, Düsseldorf/ Wien.

Meiners N., Reidl A., Seeberger B., 2011, Megatrend Alter - Eine bislang verschmähte Konsumentengruppe verändert die Wirtschaft, „HeilberufeSCIENCE (HBSc)“, Vol. 2, No. 2.

Meiners N., Schwarting U., Seeberger B., 2010, The Renaissance of Word-of-Mouth Marketing: A 'New' Standard in Twenty-First Century Marketing Management?!, "International Journal of Economic Sciences and Applied Research (IJESAR)", Vol. 3 No. 2.

Meiners N., Seeberger B., 2012, Jenseits der werberelevanten Zielgruppe: Eine Untersuchung über die Wahrnehmung und Wirkung von Werbeanzeigen bei älteren Menschen ab 50 Jahren, „Sozialer Fortschritt“", Vol. 61, No. 4.

Miller D. W., Leyell T. S., Mazachek J., 2004, Stereotypes of the elderly in U.S. television commercials from 1950s to the 1990s, "International Journal of Aging and Human Development", Vol. 58, No. 4.

Moore T. E., Cadeau L., 1985, The representation of women, the elderly and minorities in canadian television commercials, "Canadian Journal of Behavioural Science", Vol. 17, No. 3.

Prieler M., 2008, Silver advertising: Elderly people in Japanese TV ads, [in:] The Silver Market Phenomenon: Business Opportunities in an Era of Demographic Change, F. Kohlbacher, C. Herstatt (eds.), Springer Verlag, Heidelberg.

Renn U., 2006, Altersdiskriminierung aus Sicht älterer Menschen, [in:] Altersdiskriminierung - Alterspotenziale. Wie sieht der Alltag aus? Dokumentation der Veranstaltung am 12. Dez: 2005 im Maternushaus in Köln, Kuratorium Deutsche Altershilfe (eds.), farbo print + media, Köln.

Robinson J. D., Skill T., Turner J. W., 2004, Media usage patterns and portrayals of seniors, [in:] Handbook of Communication and Aging Research, K. F. Nussbaum, J. Coupland (eds.), Routledge Verlag, Mahwah.

Robinson J.D., Skill T., 1995, The invisible generation. Portrayals of the elderly on prime-time television, "Communication Reports", No. 8.

Röhr-Sendlmeier U. M., Ueing S., 2004, Das Altersbild in der Anzeigenwerbung im zeitlichen Wandel, „Zeitschrift für Gerontologie und Geriatrie“, Vol. 37, No. 1.

Rößler I., Ungerer A., 2008, Statistik für Wirtschaftswissenschaftler, Physica Verlag, Heidelberg. Rothermund K., Mayer A.-K., 2009, Altersdiskriminierung - Erscheinungsformen, Erklärungen und Interventionsansätž, Kohlhammer Verlag, Stuttgart. 
Roy A., Harwood J., 1997, Underrepresented, positively portrayed: Older adults in television commercials, "Journal of Applied Communication Research", Vol. 25, No. 1.

Schaich E., Münnich R., 2001, Mathematische Statistike für Ökonomen, Vahlen Verlag, München.

Schmidt D. F., Boland S. M., 1986, Structure of impressions of older adults: evidence for multiple stereotypes, "Psychology and Aging", Vol. 1, No. 3.

Schmitt E., 2004, Altersbild-Begriff, Befunde undpolitische Implikationen, [in:] Enzy/klopädie der Gerontologie, A. Kruse, M. Martin (eds.), vorm. Verlag Hans Huber, Bern.

Schmitz-Scherzer R., Backes G., Friedrich I., Karl F., Kruse A., 1994, Ressourcen älterer und alter Menschen. Expertise im Auftrag des Bundesministeriums für Familie und Senioren, Kohlhammer Verlag, Stuttgart.

Scholl A., 2006, Diskriminierung im Alltag älterer Menschen - eine Einführung, [in:] Altersdiskriminierung - Alterspotenziale. Wie sieht der Alltag aus? Dokumentation der Veranstaltung am 12. Dez. 2005 im Maternushaus in Köln, Kuratorium Deutsche Altershilfe (eds.), farbo print + media, Köln.

Schorb B., Hartung A., Reißmann W., 2009, Ideen und Anlage dieses Buches, [in:] Medien und höheres Lebensalter, B. Schorb, A. Hartung, W. Reißmann (eds.), VS Verlag für Sozialwissenschaften, Wiesbaden.

Sechster Bericht zur Lage der älteren Generation in der Bundesrepublik Deutschland, 2010, Altersbilder in der Gesellschaft. Bundesministerium für Familie, Senioren, Frauen und Jugend (eds.), Bundesanzeiger Verlagsgesellschaft, Berlin.

Sonnenschein B., 2008, HORIZONT"-Exklusivstudie: Werbung kommt bei Senioren nicht an, http://www.horizont.net/aktuell/marketing/pages/protected/HORIZONTExklusivstudie-Werbung-kommt-bei-Senioren-nicht-an_78217.html (retrieved: 12.08.2014).

Statistisches Bundesamt, 2009, Bevölkerung Deutschland bis 2060, https:/ /www.destatis.de/ DE/Publikationen/Thematisch/Bevoelkerung/VorausberechnungBevoelkerung/ BevoelkerungDeutschland2060Presse5124204099004.pdf?_blob=publicationFile (retrieved: 05.11.2014).

Stereotype? Frauen und Männer in der Werbung, 2008, C. Holtz-Bacha (eds.), VS Verlag für Sozialwissenschaften, Wiesbaden.

Swayne L. E., Greco A. J., 1987, The portrayal of older Americans in television commercials, "Journal of Advertising", Vol. 16, No. 1.

Tupper M., 1995, The Representation of Elderly Persons in Primetime Television Advertising, nicht publizierte Magisterarbeit, University of South Florida, Tampa.

Wilbers J., 1986, Die Behandlung von Altersfragen im Deutschen Bundestag, „Zeitschrift für Gerontologie“, Vol. 19, No. 1. 